\title{
近代詩人萩原朔太郎の撮影した写真が捉えた 風景要素に関する検討
}

A Study on the Factors of Landscape in the Photographs by the Modern Poetry Sakutaro Hagiwara

\author{
堟田 伸也 ${ }^{*}$ 森田 哲夫 ${ }^{* *}$ 湯沢 昭 ${ }^{* * *}$ 橋本 隆 ${ }^{* * * *}$ 関屋夕紀子***** \\ 入澤覚** \\ Shinya TSUKADA Tetsuo MORITA Akira YUZAWA Takashi HASHIMOTO \\ Yukiko SEKIYA Kaku IRISAWA
}

\begin{abstract}
The purpose of this study is to clarify the characteristics of landscape in the great modern poetry Sakutaro HAGIWARA by analyzed his photographs and his poems. The main conclusions were as follows; (1) The scenery of his original photographs had proposed two points of view; "the photographs of the place where Maebashi-City and Kamakura were material of landscape which was esteemed", "the photographs of the place in Tokyo and Osaka were the human activity and the townscape". (2) The element of landscape by his photographs could be divided into 6th groups scene of " 1 group of the wheels and the activity", "2 group of the animals", " 3 group of the station and the stones", "4 group of the street, the sky, the tree, the building the institution and man", " 5 group of the trees, the land and mountain", "6 group of the water, the shore and the bridge". (3) The poetic word was compared with the word analyzed by the qualification theory of 3 . It became clear that the words of all the landscape elements appeared as a poetic words. As a result, it is possible for research on his poetry to regard the spatial characteristic and the photographs.
\end{abstract}

Keywords : Factor, Landscape, Modern poet, Sakutaro Hagiwara, Photograph

キーワード : 要素, 風景, 近代詩, 萩原朔太郎, 写真

\section{1.はじめに}

風景は，人にかかわりなくあるものではなく，人のあり方に応 じてさまざまな形で現れるものである。風景の構図は, 人の視点 のわずかな摇らぎに応じて一変するものである。また，風景を語 る言葉によっても見えるものが異なるため, 同一の構図であって 屯万人が同じ風景を体験できる訳でない。さらに, 風景の味わい や気配は人の好みや想像力に頼るところが大きいとされる。

風景は, このように人の主観に強く依存して現れるものである が，都市や村の成り立ちや自然条件と全く無関係ではない。人の 住む場所の地理的構造や歴史は風景そのものではないが，風景の 母胎であるからである ${ }^{1}$ 。

この風景の母胎となる都市や村の成り立ちや自然条件を視覚的 に捉えたものとして風景写真がある。風景写真は, 特定の場所か ら見た一定の範囲をシーンとして固定した景観表現であり, シー ンとして捉えて操作する構図論が成立する。篠原は, 操作論的な 立場から景観構成要素の位置づけを明確にするため, 視点, 主対 象, 視点場, 対象場の概念を示している ${ }^{2)}$ 。

風景写真を扱った最近の既往研究としては, 観光客が撮影した 写真を用いて観光行動と観光対象としての集落風景を評価した羽 生らの研究 ${ }^{3)}$, 居住者が撮影した写真を用いて農村の地形特性か ら捉えた青野らの風景喏好の研究 ${ }^{4)}$, 天竜川の沿川における新旧 の写真集を用いて景観の変容を検討した平岡の研究 ${ }^{5}$ があるが, これらの研究はある特定の撮影者に着目して行った研究でない。

風景に関する文学作品や絵画表現は, 人間の風景観を把握する 上で有力なデータであり, 人間の感情フィルターを通じて認識さ れた心象空間ともいえる。このため背景となった社会情勢や基本

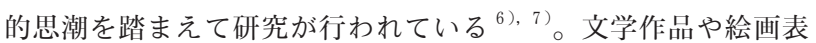
現に着目して行った先行研究としては, 夏目漱石の作品中に見る 庭園観を考察した神田らの研究 ${ }^{8)}$, 江戸後期の図絵集に描かれた
瀬戸内海の風景, 明治期の豪渓と寒霞渓との漢文学の関係に着目し た西田の研究 ${ }^{9)}$, 和歌や俳句などの文学作品や絵画作品における柿 の風景としての表現を分析した工藤らの研究 ${ }^{10)}$ があるが，近代詩 と風景との関係について扱った研究は少ない。詩は作者の内面的な 感情を, 圧縮した形で直接的に表現した文学作品の 1 つであること から，大きな想像力を掻き立てる風景の表現が存在すると考える。

そこで, 本研究では, わが国の近代詩に大きな影響を与えた詩 人である萩原朔太郎に着目し, 彼の撮影した写真と, 作品（詩） との関係について研究を行う。萩原朔太郎は, 自らの撮影した写 真について,「元來, 僕が寫眞機を持ってるるのは, 記綠寫眞の メモリィを作る爲でもなく，また所謂藝術寫眞を寫す爲でもない。 一言にして盡せば，僕はその器械の光学的な作用をかりて，自然 の風物の中に反映されている，自分の心の郷愁が寫したいのだ。」 と心象風景との関連を示唆している。また, 前橋市を同郷とする 詩人であり, 萩原朔太郎の研究者でもある伊藤信吉は,「私ども の詩的世界には, カメラアングルと呼ばれるそれぞれの対象把握 の空があり, それが萩原さんにおいて, 多少とも詩的表現にかか わりがあった」と述べ写真と詩との関連性について述へている ${ }^{11}$ 。 そこで本研究では, 我が国の近代詩に大きな影響を与えた詩人 である萩原朔太郎が撮影した写真を客観的に捉え直すことにより, 彼の風景観について基礎的な知見を得ることを目的とする。

\section{2. 研究方法}

\section{(1) 着眼点}

萩原朔太郎に関する研究は, 詩に登場する動物や植物などのイ メージの特徴を西洋の文学や哲学と比較した研究 ${ }^{12)}$ や詩観とメ ディアとの関連に着目した研究 ${ }^{13)}$, 詩学からアプローチをした 研究 ${ }^{14)}$ をはじめ, 人文分野で広く行われている。一方，近代詩 人の中で萩原朔太郎は, 研究が多く蓄積されているものの詩史上

\footnotetext{
*前橋市都市計画部 $\quad * *$ 群馬工業高等専門学校都市環境工学科 $\quad * * *$ 前橋工科大学工学部社会環境工学科 $\quad * * * *$ 伊勢崎市企画部 
における彼の位置は確定しておらず，作品が理解しがたいとされる。 これは客観的考察が十分でないことが原因とされている ${ }^{15)}$ 。郷 土をはじめ, 場所と詩との結びつきは, 詩的生命の基本であり人 間的気質や情操, 思想が, いかに成熟したかを把握することがで き，心情的郷土意識と詩的情操に脈絡するとの見方がある ${ }^{16)}$ 。

そこで本研究では, 萩原朔太郎が撮影した写真をシーン景観の 事例として構図と場所の特性を客観的に評価する。そして, 萩原 朔太郎自身の作品（詩）を重ねることによって, 写真と作品（詩） とのに関連性について検討を行うことを着眼点とする。

\section{(2) 研究フロー}

本研究が分析の対象とする資料は, 前橋市立図書館に保存され, 現在においては，前橋文学館で所蔵されており，同館によって写 真集としてまとめられた「萩原朔太郎撮影写真集一完全版一」(み やま文庫）に収録される萩原朔太郎自身が撮影を行った 114 枚の 写真とする ${ }^{17)}$ 。

研究フローを図ー 1 に示す。研究は, まず 114 枚の写真の特徽 を探るため, 計 4 名の被験者 ${ }^{18)}$ が, 撮影された写真について 1 枚 ごとに, 被写体に捉えられる対象の名称を自由記述により抽出した。 自由記述により抽出した名称は, 塚本らによる既往研究 ${ }^{19)}$ を参考 にしながら, KJ 法を適用して代表的な 123 の対象を 17 の景観要 素としてまとめた（表－1）。次に，114 枚の写真についての「主 対象」及び「視点場」を自由記述によって回答を得た。視点と主 対象との上下関係では,「水平」,「俯瞰」,「仰瞰」の 3 つの選択に よって回答を得た。さらに，114 枚の写真に含まれる全ての景観 要素を抽出するため, 1 枚の写真ごとに「対象場」として前述し た景観要素に該当すれば「1」を, 該当しなければ「0」として回 答を得た ( 3 章)。上記の結果については, 数量化理論第而類を適 用して分析を行った ( 4 章- 1$)$ 。数量化理論第正類により, 得ら れた景観要素のカテゴリスコアを解釈することによって軸の意味 づけを行った。この軸に撮影した場所別に整理を行ったサンプル スコアを布置し, 場所別による景観要素の構成について特性を探っ た ( 4 章- 2$)$ 。また, 数量化理論第正類による分析で得られた景 観要素のカテゴリスコアについては，クラスター分析を適用する ことで類型化し，萩原朔太郎自身が撮影した写真の総体的な特性 を探った（4 章一 3 )。さらに, 萩原朔太郎の代表する作品（詩） をテキストデータとして用い, 形態素解析を適用することで単語 の抽出を行い, 萩原朔太郎の撮影した写真と作品との関連性につ いて検討を行った（4 章一 4$)$ 。以上の分析結果を踏まえて, 萩原 朔太郎の撮影した写真についての客観的な特性, 及び作品との関 連について得られた知見にもとづき考察を行った（ 5 章)。

\section{3．萩原朔太郎の撮影した写真}

\section{(1) 分析対象}

萩原朔太郎が写真とかかわった時期は, 自身が 16 歳から 53 歳 までの 37 年間であるとされる。分析対象とした写真集において, 収録されている最屯古い写真は, 明治 35 年 (1902 年) に群馬県 前橋市の生家で撮影された萩原医院の病室新築工事である。撮影 写真は, オリジナルプリント 18 枚, ガラス乾板 67 枚, フイルム ネガ 29 枚の 3 種類を原板としている。

撮影時期は，40 枚が不明となっているが，それ以外の写真は， 9 枚が明治時代, 50 枚が大正時代，15 枚が昭和時代であり，撮 影年が判明している大正 10 年から大正 15 年（1921 1926 年） の写真が最も多く 29 枚である。撮影場所は 38 枚が不明であるが, 撮影場所が明らかな写真では, 父の出生場所である大阪府（池田 市，八尾市）が 4 枚, 39 歳の時に妻の健康のため一時的に転居 した神奈川県の鎌倉が 22 枚となっている。また，晚年の居住地 である東京都（千代田区，大田区，台東区，明治神宮）が 12 枚, 出生から 38 歳まで居住した群馬県前橋市が最も多く 37 枚, 群馬

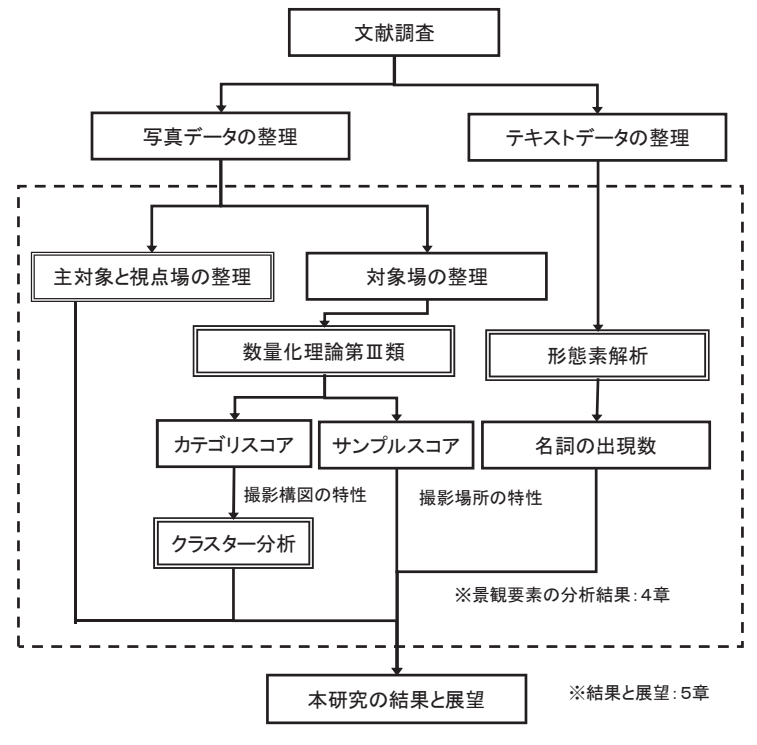

図-1 研究フロー

表 -117 の景観要素

\begin{tabular}{|c|c|c|c|c|c|c|}
\hline 車(6) & 自動車 & 自転車 & 乳母車 & 人力車 & 列車 & 馬車 \\
\hline 動物(3) & 犬 & 馬 & 鳥 & & & \\
\hline 石(4) & 石 & 石垣 & 石疊 & 石造 & & \\
\hline \multirow{3}{*}{ 水(16) } & 水際 & 海 & $川$ & 湖 & 沼 & 水 \\
\hline & 湖 & 水辺 & 河原 & 川辺 & 中洲 & 砂浜 \\
\hline & 池 & 流れ & 波 & 水路 & & \\
\hline 岸·崖(6) & 岸 & 崖 & 斜面 & 堤防 & 乒 & 峠 \\
\hline 道(4) & 道 & 坂 & 路 & 街路 & & \\
\hline 橋(4) & 橋 & 吊橋 & 八橋 & 栈橋 & & \\
\hline \multirow{3}{*}{ 建物/街並(16) } & 建物 & 建築物 & 軒 & 田舎 & $\begin{array}{ll}\text { 都 } \\
\end{array}$ & 家屋 \\
\hline & 階段 & $\bar{\Gamma}$ & 村落 & 㟤 & 㝕 & 墀根 \\
\hline & 店埔 & 家 & 屋台 & 小屋 & & \\
\hline 空(3) & 雲 & 空 & 天 & & & \\
\hline \multirow{2}{*}{ 樹木/独(7) } & 木(単) & 松 & 桜 & 生垣 & 低木 & 花 \\
\hline & 盆栽 & & & & & \\
\hline 樹木/群(6) & 木(群) & 林 & 河畔林 & 樹林 & 森 & 並木 \\
\hline 広場·駅(6) & 地面 & 広場 & 野外劇場 & 公園 & 駅 & 停車場 \\
\hline \multirow{2}{*}{ 田畑·草地(8) } & 野原 & 草地 & 湿原 & 芝生 & 田畑 & 庭 \\
\hline & 緑地 & 平野 & & & & \\
\hline \multirow{4}{*}{ 工作物(19) } & 工作物 & 櫓 & 電柱 & ポスト & 壁 & 機械 \\
\hline & 休㮩所 & 煙突 & 看板 & 送電線 & テーブル & ベンチ \\
\hline & 照明灯 & 仏像 & 旗 & 風船 & ブランコ & 鳥居 \\
\hline & 灯篭 & & & & & \\
\hline \multirow{2}{*}{ 人(8) } & 人 & 大人 & 子供 & 着物 & 帽子 & 臽 \\
\hline & 男女 & 体 & & & & \\
\hline 山(2) & 山 & 島 & & & & \\
\hline 交流(5) & 交流 & 遊び & 賑わい & 商い & お祭り & \\
\hline
\end{tabular}

県の山間部である榛名湖が 1 枚となっている。表 -2 は, 114 枚 の写真について, 主対象, 視点場, 視点と主対象の上下関係, 対 象場の景観要素の出現について調査の結果を示したものである。 調査は, 判別に恣意が生じないよう性差, 年齢を考慮し 4 名の被 験者に判別してもらった。

\section{(2) 主対象亡視点場, 視点と主対象の上下関係}

撮影写真の主対象は, 対象場の中で性格を規定し, 他の対象を 景観的に支配する対象である。主対象は，自由記述で回答しても らった上で, 表一 1 の景観要素に括った（表－2）。3 名以上の 判別一致率 ${ }^{20)}$ は比較的に高く $95.1 \%$ でった。主対象は，「人」 之「建物 / 街並」に各々 2 名で判別が分かれた写真が 2 枚あった。 原因として，写真を判別する際に，「人」として個体を主対象に 捉える被験者と「建物 / 街並」として総体を主対象に捉える被 験者がいることが考えられた。各々 2 名で判別が分かれた主対象 の写真については，「建物 / 街並 - 人」と併記した。

主対象の景観要素は,「人 (35)」が最も多くを占め, 「建物 / 街並 (25)」, 「樹木 / 群 (11) 」, 「山 (8)」, 「水 (7)」, 電柱など「工 作物 (6) 」, 「橋 (6)」, 「樹木 / 独 (6) 」, 「田畑・草地 (4) 」, 屋 台などの「交流 (2)」，馬や犬など「動物（2)」の写真があった。 撮影写真の視点場は, 視点近傍の空間の連続性から仮想して, 自 由記述により，判断してもらった。結果，3名以上の判別一致率 
表 -2 調査対象写真と評価結果の一覧表

\begin{tabular}{|c|c|c|c|c|c|c|c|c|c|c|c|c|c|c|c|c|c|c|c|c|c|c|}
\hline 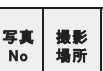 & 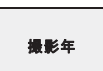 & 原板 & 三好象 & 視点堨 & 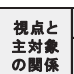 & \multicolumn{17}{|c|}{ 素の買 } \\
\hline 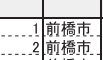 & 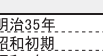 & 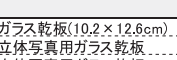 & & 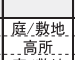 & 永永垔 & & & & & & & & & & & & & & & & & \\
\hline 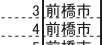 & & & & 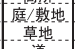 & 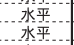 & & & & & & & & & & & & & & & & & \\
\hline 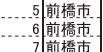 & 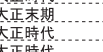 & 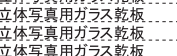 & 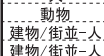 & 榃 & 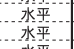 & & & . & 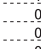 & & & & & & & & & & & & & \\
\hline & 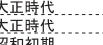 & & 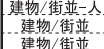 & 黄 & 永被 & & & $\ldots$ & $\cdots$ & & & & & & & & & & & & & \\
\hline & 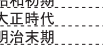 & 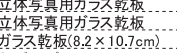 & 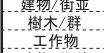 & 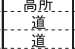 & 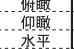 & & & & $\cdots$ & & & & & & & & & & & & & \\
\hline 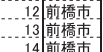 & 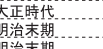 & 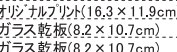 & 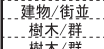 & 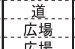 & 水水乲 & & & & & & & & & & & & & & $\cdots$ & & & \\
\hline 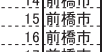 & 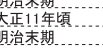 & 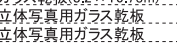 & & 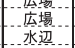 & 沝 & & & & & & & & & & & & & & & & & \\
\hline 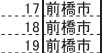 & 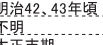 & 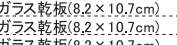 & 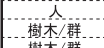 & 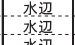 & 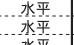 & & & & & & & & & & & & & & & & & \\
\hline 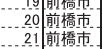 & 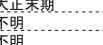 & 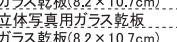 & & 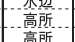 & 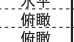 & & & & & & & & & & & & & & & & & \\
\hline 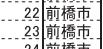 & & 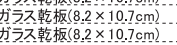 & 酎㛃 & 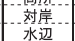 & & & & & & & & & & & & & & & & & & \\
\hline 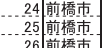 & A & 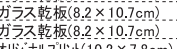 & 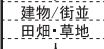 & 凅 & 永 & & & & & & & & & & & & & & & & & \\
\hline 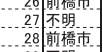 & 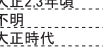 & 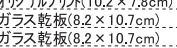 & 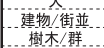 & 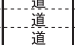 & & & & & & & & & & & & & & & & & & \\
\hline 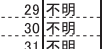 & & 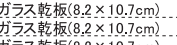 & 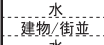 & 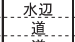 & 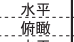 & & & & & & & & & & & & & & & & & \\
\hline 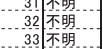 & & 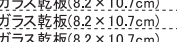 & & 逜 & & & & & & & & & & & & & & & & & & \\
\hline 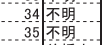 & & 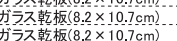 & & 䈉部 & & & & & & & & & & & & & & & & & & \\
\hline 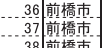 & 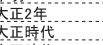 & 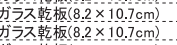 & & 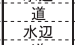 & 泉社 & & & & $\ldots$ & $\cdots$ & & & & & & & & & & & & \\
\hline 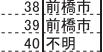 & 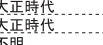 & 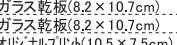 & & 遒 & & & & & & & & & & & & & & & 8 & & & \\
\hline 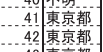 & 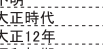 & 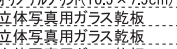 & 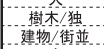 & 薄 & 等䇥 & & & & & & & & & & & & & & $\cdots$ & & & \\
\hline 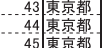 & 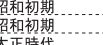 & 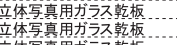 & 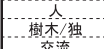 & 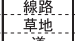 & 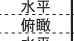 & & & & & $\ldots$ & $\ldots$ & & & & & & & & $\cdots$ & $\cdots$ & & \\
\hline 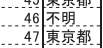 & 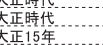 & 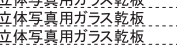 & & 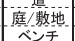 & 等䓠 & & & & & & & & & & & & & & & & & \\
\hline 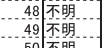 & 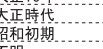 & 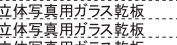 & 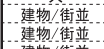 & ‥ & 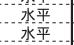 & & & & & $\ldots$ & & & & & & & & & & & & \\
\hline 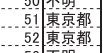 & 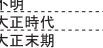 & 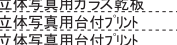 & & 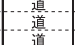 & & & & & & & & & & & & & & & & & & \\
\hline & & 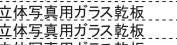 & 㢣 & 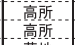 & & & & & & & & & & & & & & & & & & \\
\hline & 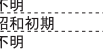 & 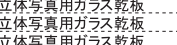 & & 酎地 & 觮 & & & & & $\ldots$ & & & & & & & & 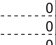 & & & & \\
\hline 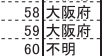 & 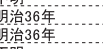 & 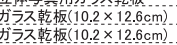 & & 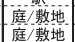 & 永 & & & & & & & & & & & & & & & & & \\
\hline 䄷䐓 & & 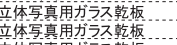 & 㴶棤 & 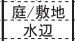 & 永 & & & & & & & & & & & & & & & & & \\
\hline 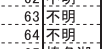 & 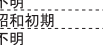 & 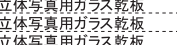 & & 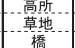 & 楾 & & & & & & & & & & & & & & & & & \\
\hline 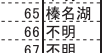 & 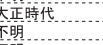 & 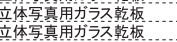 & & 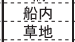 & & & & & & & & & & & & & & & & & & \\
\hline & & 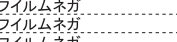 & 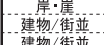 & 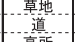 & & & & & & & & & & & & & & & & & & \\
\hline & & & & 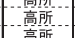 & & & & & & & & & & & & & & & & & & \\
\hline & & & 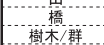 & 童碚 & & & & & & & & & & & & & & & & & & \\
\hline & & 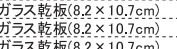 & 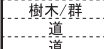 & 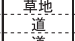 & 永 & & & & & & & & & & & & & & & & & \\
\hline & & & 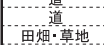 & 覀地地 & 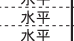 & & & & & & & & $\ldots$ & $\cdots$ & & & & & & & & \\
\hline 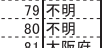 & & 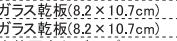 & 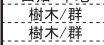 & $\begin{array}{l}\text { 道 } \\
\end{array}$ & 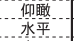 & & & & & & & & 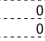 & & $\ldots$ & & & & & & & \\
\hline & 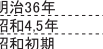 & 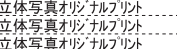 & & 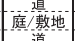 & 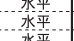 & & & & & & & & ..... & & & & & & & & & \\
\hline & 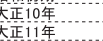 & & & 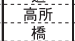 & 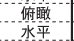 & & & & & & & & . & 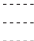 & & . & & & & & & \\
\hline & 焉1箐: & & & 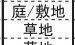 & 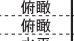 & & & & & & & & $\ldots$ & & $\cdots$ & & & & & & & \\
\hline & 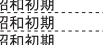 & 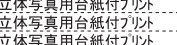 & 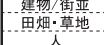 & 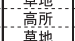 & 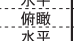 & & & & & & & & .... & & & & & & & & & \\
\hline 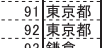 & 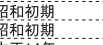 & 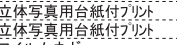 & & yz & 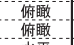 & & & & $\cdots$ & $\ldots$ & & & : & & & & & & & & & \\
\hline & 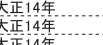 & & & 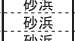 & 永 & & & & & $\ldots$ & & & & & & & & & & & & \\
\hline & 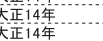 & & & 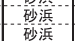 & & & & & & & & & & & & & & & & & $\ldots$ & \\
\hline & 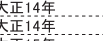 & & & 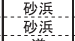 & 永 & & & & & $\ldots$ & & & $\cdots$ & & & & & & & & ... & \\
\hline & 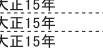 & & 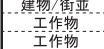 & 尊 & & & & & & $\ldots$ & & & & & & & & 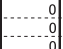 & & $\ldots$ & & \\
\hline & 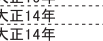 & & " & 蓭 & & & & $\ldots$ & $\cdots$ & $\ldots$ & & & $\cdots$ & & & & & & 1 & & & \\
\hline & 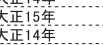 & 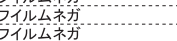 & 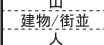 & 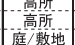 & 栵策 & & & $\cdots$ & $\cdots$ & ... & & $\because 0$ & $\cdots$ & & & & & & $\cdots 0$ & & & \\
\hline & 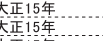 & siti & & 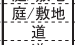 & 旅 & & & & & $\ldots$ & & & $\cdots$ & & & & & & & & & \\
\hline & 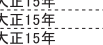 & 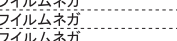 & 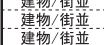 & 整 & & & & & & $\ldots$ & & & & 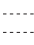 & & & & & & & & \\
\hline & 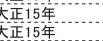 & & & 真部 & & & & & & & & & & & & & & & & & & \\
\hline & & & & & & & & & & & & & & & & & & & & & & \\
\hline & (幽珢䫈崖 & (3)もの) & 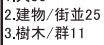 & 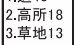 & 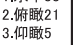 & & & ${ }^{24}$ & 36 & 27 & 62 & 13 & 59 & 8 & & 58 & 24 & 54 & 50 & 59 & 27 & \\
\hline & $(3)$ & & $95.61 \%$ & \begin{tabular}{|l|l|}
$90.40 \%$ \\
\end{tabular} & $100 \%$ & & 80.006 & 36.928 & 51.438 & 49098\% & 79.498: & 60.878 & $85.51 \%$ & 89.58 & 92.31 & $71.60 \%$ & 63.1680 & 71.058 & $65.448 \mathrm{~g}$ & $85.51 \times$ & $60.00 \mathrm{~s}$ & \\
\hline
\end{tabular}


表－3 数量化理論第而類による分析結果

\begin{tabular}{|c|c|c|c|c|}
\hline カテゴリ & 第1軸 & 第2軸 & 第3軸 & 第4軸 \\
\hline 固有値 & 0.416 & 0.252 & 0.167 & 0.135 \\
\hline 寄与率 & 0.235 & 0.142 & 0.094 & 0.076 \\
\hline 累積寄与率 & 0.235 & 0.377 & 0.471 & 0.547 \\
\hline 相関係数 & 0.645 & 0.502 & 0.408 & 0.367 \\
\hline カテゴリ & 第1軸 & 第2軸 & 第3軸 & 第4軸 \\
\hline 車 & 2. 157 & -2.312 & 3. 980 & 0.253 \\
\hline 動物 & 2. 564 & 3. 630 & 2. 419 & 2. 311 \\
\hline 石 & 0.571 & 1. 754 & -1.897 & -1.815 \\
\hline 水 & -1.114 & 0.871 & 1. 265 & -0.619 \\
\hline 岸崖 & -1.223 & 1.050 & 1. 391 & -1.726 \\
\hline 道 & 0.066 & -0.806 & -0.092 & -0.078 \\
\hline 橋 & -1.383 & 0.696 & 1.479 & -3.178 \\
\hline 建物/街並 & 0.488 & -1.395 & -0.867 & -0.163 \\
\hline 空 & -0.172 & -0.554 & -0.055 & -0.023 \\
\hline 樹木/独 & -0.372 & -0.438 & -0.812 & 0.343 \\
\hline 樹木/群 & -0.993 & 0.099 & 0.111 & 0.965 \\
\hline 広場 - 駅 & 1.298 & 2. 686 & -1.069 & 1.675 \\
\hline 田畑 - 草地 & -1.014 & 0.125 & -0.147 & 0.279 \\
\hline 工作物 & 1.273 & 0.006 & -0.540 & -0.312 \\
\hline 人 & 1.142 & 0.368 & 0.111 & -0.786 \\
\hline 山 & -1.411 & 0.289 & 0.445 & 2. 341 \\
\hline 交流 & 2. 289 & -1.045 & 2. 981 & 0.785 \\
\hline 軸の解釈 & 自然－都市 & 日常－余暇 & 静一動 & 川辺－山間 \\
\hline
\end{tabular}

が 90.4\%であり，各々 2 名で判定が分かれたものは無かった。

視点場は, 「道 (43)」が最も多くを占め, 「高所 (18)」, 「草地 (13)」，「庭 / 敷地 (9)」，「水辺 (10)」，「砂浜 (7)」の写真があった。 撮影写真の視点と主対象の関係では,「水平」,「俯瞰」,「仰瞰」 の 3 つの選択で判別してもらった。3名以上の判別一致率が $100 \%$ あった。視点と主対象の上下関係の判別結果は,「水平 (88)」が最も多く，「俯瞰（21）」，「仰瞰（5）」の写真があった。

\section{4. 撮影写真の対象場の特徵}

\section{(1) 対象場の出現亡数量化理論第川I類による分析}

対象場は, 前章で示した方法によって設定した 17 の景観要素 について, 各々の写真の対象場として確認できれば「1」を記入し, 該当しなければ「0」を記入してもらった。調査結果は，被験者 4 名のうち 3 名以上の判別が一致したものを有効として採用し, 4 名が各々 2 名に分かれた時は判定を棄却した。対象場の出現総 数における被験者 3 名以上の判別一致率は $70.23 \%$ あった。景 観要素別に判別一致率に着目すると，「樹木 / 独 (92.31\%)」,「空 (89.58\%)」，「人 (85.51\%)」が高い值になったのに対して，「岸・ 崖 (49.09\%)」，「交流(43.24\%)」，「石（36.92\%)」が低い值と なった。「岸・崖」,「交流」，「石」の判別一致率が低い值となっ た原因としては, 経年によって写真そのものが劣化していること, 景観要素の定義が不明瞭であり抽出に偏りがあること, 被写体を 個体として細部まで抽出する被験者（例えば道にある転石をカウ ントするケース）と集合体として捉えることによって細部につい て抽出しない被験者（道としてカウントし，転石は抽出しないケー ス）があることが考えられた。

景観要素の中で出現数が最も多かったものは，「空 (86)」となっ た。また, 「樹木 / 独 (72)」, 「道 (62)」, 「建物 / 街並 (59)」, 「人 (59)」, 「樹木 / 群 (58)」, 「田畑・草地 (54)」, 「工作物 (50)」, $\lceil$ 水 (36)」, 「岸・崖 (27)」,「山（27）」, 「石（24）」, 「交流 (16)」, 「橋（13）」，「動物（8）」，「車（8）」という結果となった（表－2）。

さらに，これら景観要素間の関連性について把握することを目 的に数量化理論第III類を適用して分析を行った。表一 3 は数量化 理論第正類による分析の結果について, 各々の固有値, 寄与率を 示したものであり 4 軸を抽出した後の累積寄与率は 0.547 であった。

図 -2 は，数量化理論第正類の分析によって得られた第 1 軸と 第 2 軸について, 得られた各々のカテゴリスコアの值を布置した 屯のである。第 1 軸のマイナス方向は,「山」,「橋」,「岸・崖」, 「樹木 / 群」など, 山や樹木など自然に関するカテゴリが付置さ

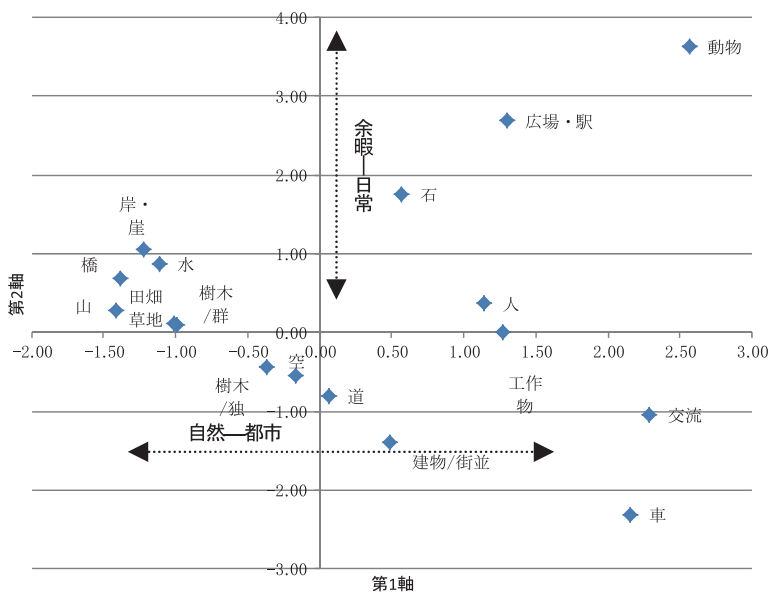

図－2カテゴリ別のカテゴリスコアの分布

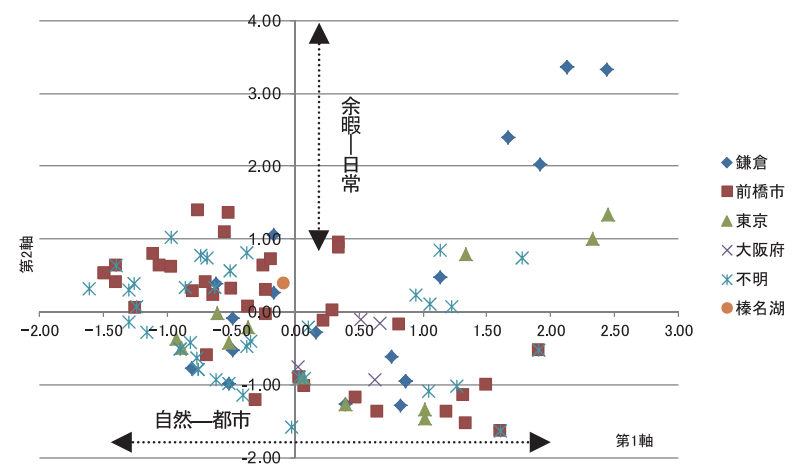

図－３撮影場所別のサンプルスコアの分布

れることから，「自然」と意味づけを行った。第 1 軸のプラス方 向は, 「動物」,「交流」,「車」が布置しており, 人が生活を営む 上で必要な機能に関係するカテゴリが付置されることから「都市」 と意味づけし，第 1 軸を「自然一都市」と意味づけを行った。

第 2 軸のマイナス方向は, 「車」,「建物 / 街並」,「交流」といっ た日常生活に関する景観要素が布置されることから，「日常」と 意味づけを行った。第 2 軸のプラス方向は，「動物」，「広場・駅」 など余㗇・レクリエーションに関する景観要素が布置されること から，「余㗇」と意味づけし，第 2 軸を「日常一余㗇」と意味づ けを行った。同様に，第 3 軸のマイナス方向は，「石」，「広場・駅」 など固定したイメージのある景観要素があり，第 3 軸のプラス方 向に「車」,「交流」，「動物」など，動きのあるイメージのある景 観要素があることから, 第 3 軸を「静一動」と意味づけを行った。 さらに, 第 4 軸のマイナス方向は,「橋」,「石」,「水」など, 川 辺をイメージする景観要素があり，プラス方向に「山」，「動物」 なよ゙，山間をイメージするカテゴリがあることから第 4 軸を「川 辺一山間」として意味づけを行った（表－3参照）。

\section{（2）対象場の場所別特性の把握}

図一 3 は，数量化理論第亚類によって得られた写真ごとのサン プルスコアについて撮影場所に分類し, 図- 2 と同様にマッピン グを行ったものである。図ー 2 と図一 3 の結果を重㸚合わせるこ とにより，萩原朔太郎の写真の撮影場所について以下の傾向を把 握することができた。まず，鎌倉を撮影場所としている写真は， 第 1 象限が 8 枚, 第 2 象限が 3 枚, 第 3 象限が 4 枚, 第 4 象限が 7 枚之全ての象限に広く分布していた。中でも第 1 象限と第 4 象 限の写真が多くを占めることから，「都市一余㗇」と「都市一日常」 を捉える対象場を多く撮影した傾向があることが分かった。

次に，前橋市を撮影場所としている写真は，第 1 象限が 3 枚， 


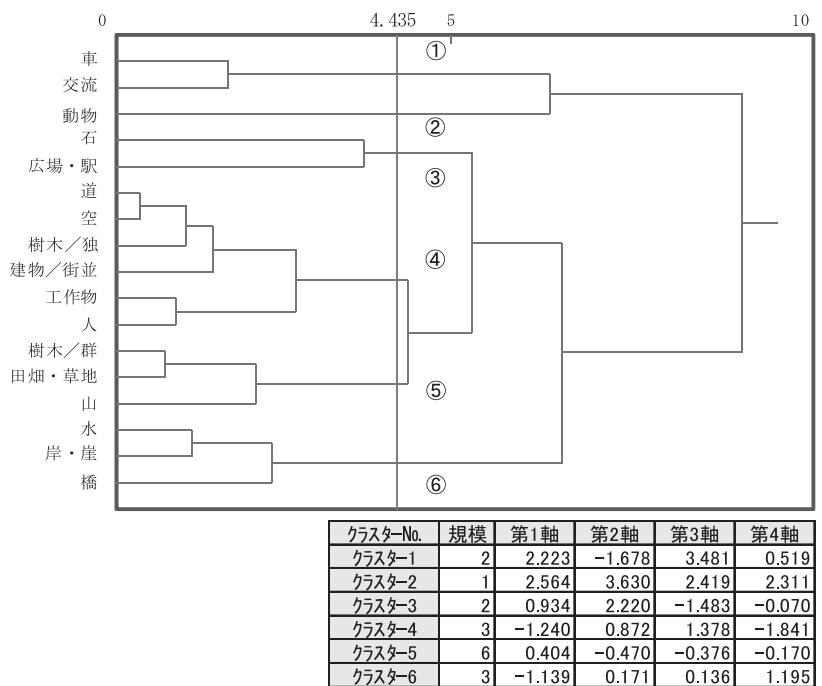

図ー4 クラスター分析による結果（デンドログラム）
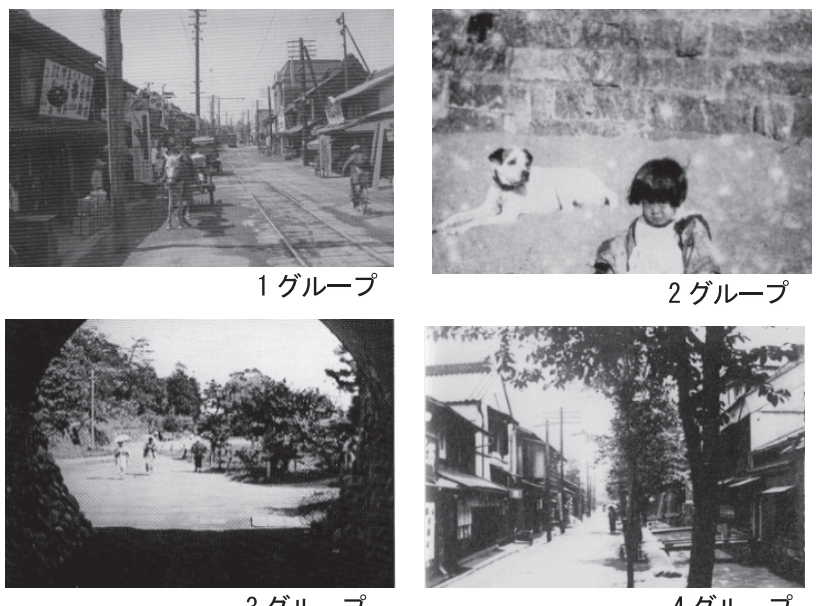

3 グループ

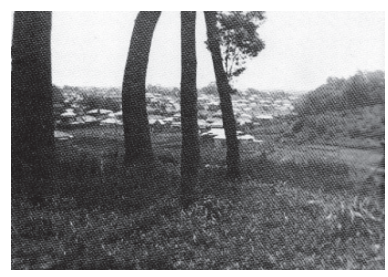

5 グループ

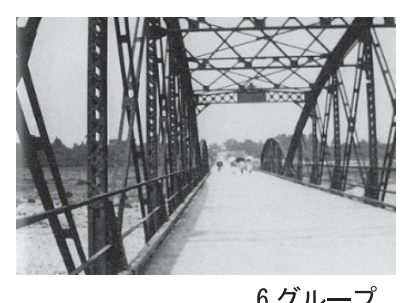

図ー 5 類型化された写真の事例

第 2 象限が 19 枚, 第 3 象限が 3 枚, 第 4 象限が 11 枚亡鎌倉之同 様に全ての象限に広く分布していた。中でも第 2 象限と第 4 象限 の写真が多くを占めることから，「自然一余暇」と「都市一日常」 を捉える対象場を多く撮影した傾向があることが分かった。

さらに, 大阪府は 7 枚の全てが第 4 象限に布置されていること から「都市一日常」, 東京都は第 1 象限に 3 枚, 第 3 象限に 5 枚, 第 4 象限に 4 枚の撮影写真が布置されていたことから，「都市一 余暇」と「都市一日常」，「自然一日常」を捉える対象場を撮影し た傾向があることが分かった。

この結果から，前橋市や鎌倉の撮影した写真が広い景観要素を 捉え，かつ自然と余暇との関わりを捉えた写真が多く存在した。 これに対して, 東京都や大阪府を撮影した写真では, 自然と余㗇 の関わりを捉えた写真 (第 2 象限) が存在せず，むしろ都市を中 心に余㗇之日常を捉えた写真が多く存在することが分かった。中 でも前橋市では自然と余暇の関わりを捉えた写真（第 2 象限）が

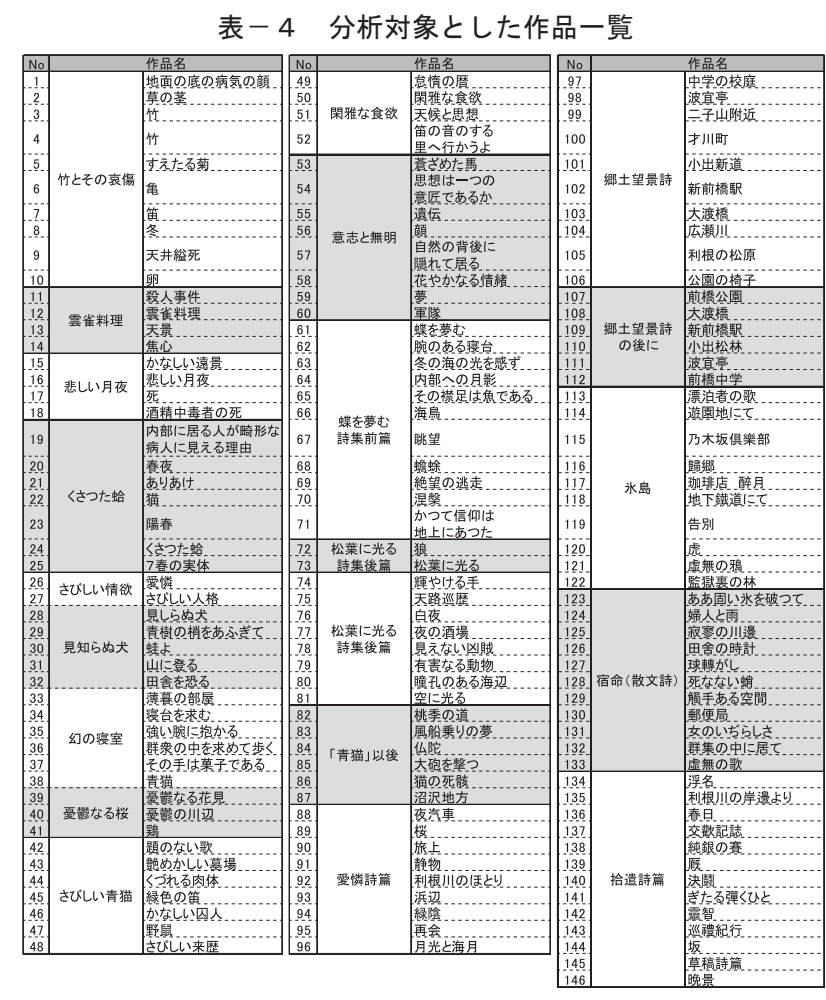

表－5 形態要素解析による関連単語の抽出

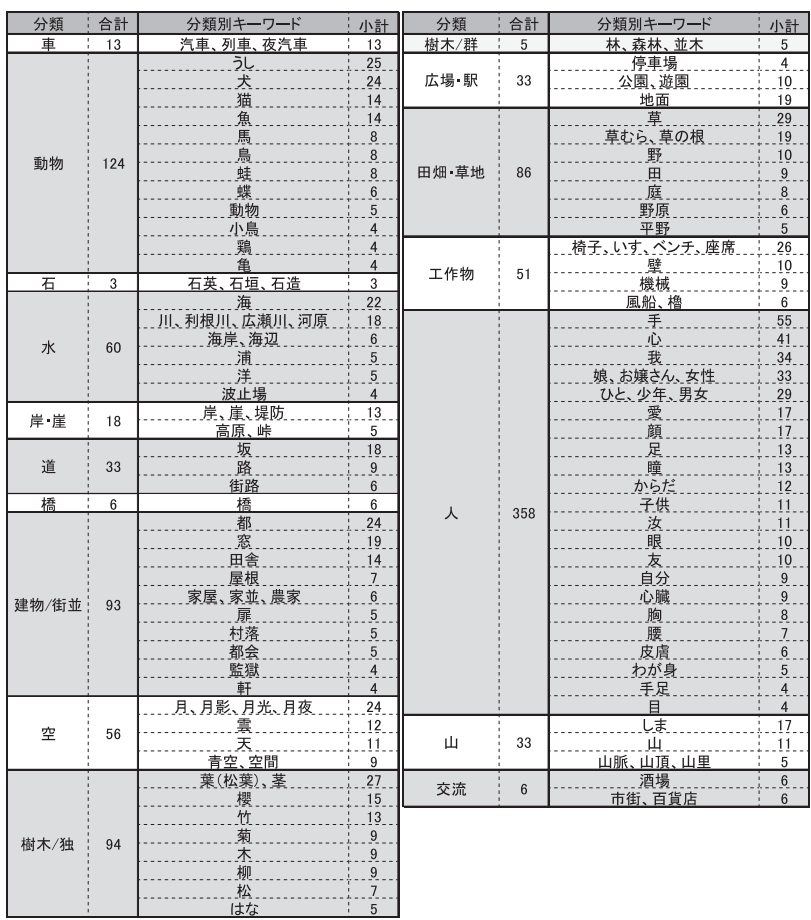

多く存在するという場所の特性を把握した。

\section{（3）対象場の総体特性の傾向}

図一 4 は数量化理論第而類によって得られた 4 軸のカテゴリス コアについて, クラスター分析（ウォード法, クラスター数 6, クラスター距離 4.435, 累積寄与率 0.547）を適用することにより 樹形図を作成したものである。図より, 次の 6 つのグループに撮 影写真の傾向を把握することができた。1グループは「車」と「交 流」で構成された写真。2 グループは「動物」で構成された写真。 3 グループは,「石」,「広場・駅」で構成された写真。 4 グループ

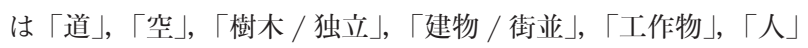


で構成された写真。 5 グループは「樹木 / 群」,「田畑・草地」「「山」 で構成された写真。6グループは「水」,「岸・崖」,「橋」で構成 された写真（図一 5 参照）となった。以上によって, 萩原朔太郎 が撮影した写真の対象場の総体的な特性を把握することができた。

（4）萩原朔太郎の作品（詩）と撮影写真の景観要素との関連

前項まで萩原朔太郎の撮影写真についての景観要素の特徵につ いて分析を進めてきた。ここでは，萩原朔太郎の作品 ${ }^{21)}$ をテキス トデータとして扱い, 景観要素との関連性について形態素解析に よる分析を行った。分析は，技術情報が公開され，多くの研究論 文で利用されている KH Coder を使用した。形態素解析とは, 文 と文章を, 言語が持つ最小単位の列に分割し, それぞれの品詞を 判別する作業である。KH Coder では形態素解析器として「茶笔 (Cha Sen)」が組み込まれている。新潮文庫の萩原朔太郎詩集に 収められた表一 4 に示した 146 個の主要な作品をテキストデータ として, 形態素解析を行い抽出された名詞と景観要素のカテゴリ に関連する単語を表一 5 に示した。結果は, 17 の景観要素のカテ ゴリに関する単語 (名詞) の全てが作品中に存在していた。数に 着目すると,「人 (358)」が最も多く, 次に「動物 (128)」,「樹木 /独立 (94)」,「建築 / 街並 (93)」があった。撮影写真の対象場 にある景観要素之比較すると, 「動物」については, 作品中の単語 に多く存在するが，撮影写真の主対象として少ない結果となった。 また，「人」，「建物／街並」「「樹木」（群又は独を含む）については, 写真の主対象や対象場，作品中の単語ともに多い傾向を把握した。

\section{5.まとめ}

\section{(1) 結果と考察}

本研究では, 萩原朔太郎の自らが撮影した写真を客観的に分析 し, 作品（詩）との関連性について検討したものである。結果に ついて以下にまとめる。

1) 撮影写真の主対象, 視点場, 視点と主対象の上下関係について 検討を行った。主対象の景観要素は「人」や「建物 / 街並」 が多く, 視点場は「道」が多い結果となった。視点と主対象の 上下関係では「水平」が多く, 対象場について 17 の景観要素 から捉えて検討した結果では, 「空」や「樹木 / 独」,「道」, 「建 物 / 街並」,「人」が多い傾向を把握した。

2) 景観要素間の関連性を把握することを目的として, 数量化理論 第正類を適用して分析を行い, 累積寄与率が最も大きい第 1 軸 と第 2 軸に撮影された場所ごとに区分してサンプルスコアをマッ ピングした。結果，前橋市や鎌倉の撮影した写真は，広い景観 要素を捉えて, かつ自然と余㗇の関わり捉えた写真が多く, 東 京都や大阪府を撮影した写真では, 都市を中心とした日常と余 暇の関わりを捉えた写真が多い傾向を把握した。

3)数量化理論第正類によって得られた 4 軸のカテゴリウェイトに ついてクラスター分析（ウォード法）を適用することにより, 萩原朔太郎が撮影した写真の対象場について 6 つのグループに 類型化した。これによって, 撮影された写真についての景観要 素について総体的な特性を把握した。

4)萩原朔太郎の作品 (詩)をテキストデータとして扱い, 景観要 素との関連性について分析を行った。結果, 17 の景観要素の カテゴリに関する単語 (名詞)を分析対象とした作品の中から 抽出することができた。

5)撮影された写真と作品について, 景観要素の出現の傾向を見る と，ともに「人」，「建物 / 街並」の出現数が多くを占めた。 また,「動物」は作品に多いが, 写真では少ない傾向を把握した。 なお,「人」,「建物 / 街並」の景観要素を含んで構成される写 真の対象場は，4 グループであり，このグループの写真之詩の 強い結びつきが推察された。

(2) 課題と展望
わが国の近代詩に大きな影響を与えた萩原朔太郎の撮影した写 真に客観的な評価を加えることによって，作品との関連性を明ら かにすることは, 客観的な考察が不十分とされる萩原朔太郎自身 の研究を省みる上で意義があると考えられる。本研究によって, 萩原朔太郎の撮影した写真を客観的な景観要素として検討した結 果，彼の作品（詩）に同様の景観要素が単語として包括的に存在 し, さらに作品において多く出現する単語で構成される写真のグ ループの傾向を見出し，推察することができた。

一方で, 今回の研究で提示した手法は, 4 名の被験者が $\mathrm{KJ}$ 法 を用いて評価を行った点や信頼性を 3 名以上の被験者の一致に頼っ ている点に扔いて, 再現性に一定の限界がある。よって, 景観要 素の抽出方法, 異なる母集団において方法の検証を継続していく 必要がある。さらには, 分析対象とした写真及び作品の景観要素 間の結び付きを定量的に把握することにより，より具体的に写真 と作品との関連性が把握できると考えるが, 今後の課題としたい。

さらに，「彼の詩的世界そのものは意外に閉鎖的なものかもし れない。とりわけ「月に陕える」や「青猫」の世界は，それが最 初の口語詩らしい口語詩の成果であるという点を除けば，はたし てどれだけ普遍性をもちえているのかいささか疑問なのである。 朔太郎の詩の世界には他者がいない。彼の自我を受けとめるべき

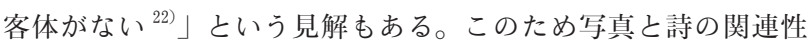
については, 背景となる社会情勢や基本的思想を十分に加えるこ とも必要であると考える。

\section{補注及び引用文献}

1 ) 中村良夫 (2001)：風景学・実践編 : 中公新書

2 ) 篠原修編 (2001) : 景観用語辞典 : 景観デザイン研究会著, 彰国社, 30-33

3 ）羽生冬佳・黒田乃生・高橋正義（2002）：白川村萩町地区における観 光行動と観光対象としての集落風景に関する研究: ランドスケープ研 究Vol.65(5), 785-788

4 ）青野幸子・加我宏之・下村泰彦・増田昇（2005）：泉北丘陵端部の農 村地域における地形特性から捉えた居住者が好む風景魅力の解明: ラ ンドスケープ研究 Vol.68(5)，753-756

5 ) 平岡直樹（2007）：天竜川沿川に打ける新旧写真比較からみる景観の 変容に関する研究 : ランドスケープ研究 Vol.68(5), pp.791-794

6 ) 池田朋子・紺野昭（1993）：文学作品中の空間描写加都市・地域景 観を読み取る方法に関する研究: 日本建築学会計画系論文報告集 No.450, 121-130

7 ）小野良平 (2005)：明治末期以降の山林の変容と「ふるさと」風景観 の成立: ランドスケープ研究 Vol.68(5), 411-416

8 ）神田圭一・鈴木誠 (2002) : 夏目漱石の庭園観に関する研究: ランド スケープ研究 Vol.65(5), 389-392

9 ）西田正憲（2007）：瀬戸内海における漢文学のまなざしに見いだされ た風景: ランドスケープ研究 Vol.70(5), 365-367

10）工藤豊・小野良平・伊藤弘・下村彰男（2007）：柿の表象表現にみる 風景観の変遷に関する研究: ランドスケープ研究 Vol.70(5), 369-372

11）前橋市教育委員会（1981）：萩原朔太郎撮影写真集 : 萩原朔太郎の巻 頭言及び伊藤信吉の序文: 上毛新聞社

12）田中雅史 (2001) : 萩原朔太郎の動物のイメージと内的体験一D.H. ロ レンス, ニーチェとの比較研究: 言語文化研究 (8), 1-12

13）安智史（2008）：萩原朔太郎というメディア一ひき裂かれる近代／詩人： 株式会社森話社

14）米倉㦑 (2001)：「純情小曲集」の「自序」論一朔太郎の詩学の根拠一: 日本大学芸術学部紀要 (34), 31-46

15）佐藤房儀 (1968) : 萩原朔太郎研究の問題点 : 日本近代文学（第八集）

16）伊藤信吉（1981）：萩原朔太郎之詩的風土：上毛新聞社

17）野口武久編（2009）：萩原朔太郎撮影写直集一完全版—：みやま文庫 発行: 朝日印刷株式会社（写真の番号については, 同誌の掲載番号を 示している)

18）被験者は，19歳女性と 21 歳男性（共に群馬工業高等専門学校環境都 市工学科学生）各 1 名，32 歳女性 1 名（景観関係コンサルタント勤 務)，40 歳男性 1 名（景観行政）の計 4 名。景観用語等について予め 十分な説明を加えた。

19）塚本俊介・下村彰男・小野良平・熊谷洋一（2001）：「自己形成期に おける風景」と居住空間の景観評価における関連性: ランドスケープ 研究 Vol.64(5), 709-712

20）判別一致率とは，4名の景観要素の判定により出現した景観要素の出 現総数によって, 3 名以上の景観要素の総数を除して百分率で示した值。 判別精度 $50 \%$ 以下が 17 カテゴリのうち 3 カテゴリであり, 総力テゴ リの 8 割以上が判別精度 50\%を満たす客観性が確保されると判断した。

21）河上徹太郎編（2004）：萩原朔太郎詩集 : 新潮社

22）渋沢孝輔（1967）：萩原朔太郎論（一)：一橋論叢 57(2), 198pp (2012.3.31 受付, 2012.8.1 受理) 